\title{
PENGGUNAAN METODE PROFILE MATCHING DAN NAÏVE BAYES UNTUK MENENTUKAN STARTING ELEVEN PADA SEPAK BOLA
}

\author{
Fabio Fahri Pratama1, Youllia Indrawaty Nurhasanah ${ }^{2}$ \\ Informatika Institut Teknologi Nasional Bandung \\ ${ }^{1}$ fabio.fahri@gmail.com \\ ²youllia@itenas.ac.id
}

\begin{abstract}
Abstrak - Pemilihan pemain starting eleven atau kesebelasan dan formasi tim dengan komposisi pemain yang tepat dalam olahraga sepak bola merupakan hal yang penting untuk meningkatkan performa permainan sebuah tim. Pelatih terkadang memilih pemain starting eleven tidak secara objektif, dikarenakan dibutuhkan keahlian dan kejelian dalam menilai kemampuan seseorang. Guna memudahkan pemilihan pemain dalam starting eleven maka dibangun sistem untuk membantu pelatih memilih posisi I deal bagi pemain dan memilih pemain secara objektif agar meningkatkan kualitas pemilihan pemain, baik dari penempatan posisi ideal pemain maupun pemilihan pemain sebagai starting. Sistem ini akan menerima input berupa nilai atribut kemampuan dan kondisi pemain yang akan diproses untuk menghasilkan output berupa rekomendasi pemain untuk dijadikan starting eleven. Dalam proses menentukan pemain, nilai atribut kemampuan pemain dilakukan proses Profile Matching (PM) untuk menentukan posisi ideal bagi pemain, dari tiap kelompok posisi dilakukan proses identifikasi menggunakan Naïve Bayes (NB) untuk menentukan pemain yang cocok untuk dijadikan starting eleven. Pengujian rekomendasi posisi dilakukan dengan membandingkan posisi asli pemain dengan posisi hasil rekomendasi dengan hasil akurasi sebesar $65 \%$, sedangkan pengujian pemilihan starting eleven dilakukan menggunakan game Football Manager dengan melakukan pertandingan dengan pemilihan pemain secara default dan pemilihan pemain hasil rekomendasi masing-masing sebanyak sepuluh kali melawan tim dengan komposisi pemain yang sama, hasil dari pertandingan tersebut dihitung selisih (\%) dari rata-rata rating pemain. Hasil yang diberikan setelah digunakan perekomendasian pemilihan pemain kenaikan rata-rata rating tim hanya naik sebesar $0.98 \%$.
\end{abstract}

Kata kunci : Nä̈ve Bayes, Sepak Bola, Profile Matching, Football Manager

\begin{abstract}
The selection of starting eleven players and team formations with the correct composition of players in soccer is important to improve the performance of a team. Coaches sometimes choose not starting players objectively, because it takes expertise and foresight in assessing one's abilities. In order to facilitate the selection of players in the starting eleven, a system was built to help the coach choose the ideal position for the players and choose players objectively to improve the quality of player selection, both from placing the player's ideal position and selecting players as starting. This system will receive input in the form of the ability and condition attribute values of the player which will be processed to produce output in the form of a player's recommendation to become the starting eleven. In the process of determining the players, the value of the attributes of the player's ability is carried out the Profile Matching (PM) process to determine the ideal position for the players, from each group of positions the identification process is done using Nä̈ve Bayes (NB) to determine the suitable players to be the starting eleven. Position recommendation testing is done by comparing the original position of the player with the position of the recommended results with an accuracy of 65\%, while testing the selection of the starting eleven is carried out using the game Football Manager by playing matches by selecting players by default and selecting the results of the recommendation players ten times each against the team with the same player composition, the result of the match is calculated as a difference (\%) from the average player rating. The results given after using the player selection recommendation increase the team's average rating to only increase by $0.98 \%$.
\end{abstract}

Keywords : Nä̈ve Bayes, Soccer, Profile Matching, Football Manager 


\section{PENDAHULUAN}

Setiap pelatih pada cabang olahraga sepak bola pasti menginginkan tim yang dilatihnya memiliki performa yang baik dan memenangkan pertandingan. Formasi tim dengan komposisi pemain yang tepat dapat meningkatkan performa tim saat bertanding.

Seorang pelatih dituntut untuk bisa melihat potensi dan kemampuan pemain yang memiliki kualitas yang bagus untuk dipilih menjadi starting eleven. Tetapi pada faktanya, pelatih masih merasa kesulitan dalam pemilihan pemain, sehingga pelatih terkadang menilai pemain tidak secara objektif (Dedi, 2015). Sulit bagi tim untuk memilih pemain jika tidak memiliki patokan untuk memilih.

Pada pemilihan pemain yang dijadikan starting eleven biasanya pelatih memiliki nilai standarnya masing-masing (Asrianda, 2019). Kemampuan pemain yang dipilih menjadi starting eleven oleh pelatih terkadang tidak memenuhi standar keinginan pelatih. Kendalanya adalah sulitnya untuk menentukan kualitas pemain, dikarenakan membutuhkan keahlian khusus dan kejelian dalam menilai kemampuan seseorang (Alprianta, 2012). Hal tersebut sangat disayangkan apabila pemain tersebut merupakan pemain mahal tetapi ternyata performanya tidak sebanding dengan harganya.

Untuk mengatasi masalah pemilihan pemain untuk dijadikan starting eleven, maka dibuatlah sistem pemilihan pemain sepak bola dalam menentukan starting eleven berdasarkan kemampuan dan kondisi pemain yang diuji coba menggunakan game Football Manager.

Penelitian yang dilakukan oleh (Ainul Yaqin, dkk., 2019) menghasilkan kesimpulan kenaikan rating rata-rata pemain setelah digunakan optimasi rekomendasi posisi ideal pemain di bawah umur 30 tahun berdasarkan nilai atribut kemampuannya menggunakan Nä̈ve Bayes sebesar 8,7\%.

Sementara itu penelitian yang dilakukan oleh (Dita Sartika, dkk., 2016) yaitu membandingkan nilai akurasi Profile Matching dengan nilai akurasi Nä̈ve Bayes untuk memilih posisi ideal pemain berdasarkan nilai kemampuan pemain menghasilkan nilai akurasi Naïve Bayes sebesar 84,21\% dan nilai akurasi Profile Matching sebesar $94,73 \%$.

Dilihat dari latar belakang, maka dilakukan penelitian yang berbeda dari penelitian sebelumnya yaitu dilakukannya proses penentuan rekomendasi posisi ideal pemain terlebih dahulu menggunakan metode profile matching lalu dilakukan proses pemilihan rekomendasi pemain untuk starting eleven menggunakan metode Nä̈ve Bayes.
Dilihat dari permasalahannya, yaitu sulitnya pelatih melihat kualitas pemain untuk dijadikan starting eleven sehingga pemilihan pemain tidak dilakukan secara objektif (Dedi, 2015) dan dibutuhkan keahlian khusus serta kejelian dalam menilai kemampuan seseorang (Alprianta, 2012), maka rumusan masalah penelitian ini adalah untuk membantu pelatih memilih posisi ideal bagi pemain dan memilih pemain secara objektif menggunakan sistem yang akan dibangun.

Ada beberapa batasan masalah saat perancangan sistem agar pembahasan tidak meluas. Berikut adalah batasan masalah:

1. Pemain yang menjadi target teliti sebanyak 20 pemain dalam satu tim.

2. Pengujian dilakukan menggunakan game Football Manager.

3. Roles yang digunakan dalam penelitian yaitu dua Central Defense, Full-Back, Wing-Back, Defensive Midfielder, Central midfielder, Attacking Midfielder, Winger, Inside Forward, dan Advanced Forward.

Penelitian ini bertujuan untuk meningkatkan kualitas pemilihan pemain oleh pelatih baik dari penempatan posisi ideal pemain maupun pemilihan pemain sebagai starting eleven.

\section{KAJIAN PUSTAKA}

\section{A. Profile Matching}

Profile matching adalah metode menentukan keputusan dengan variabel yang harus sama dengan standar (Kusrini, 2007).

Proses profile matching merupakan proses membandingkan nilai individu dengan nilai standar sehigga ditemukan perbedaan nilai nya yang disebut GAP.

Pada metode profile matching terdapat beberapa tahapan sebagai berikut:

\section{Penentuan nilai GAP}

Penentuan nilai GAP adalah perhitungan perbedaan nilai yang dimiliki seseorang dengan nilai yang diinginkan sesuai dengan standar (Setiabudi, 2012). Formula untuk penentuan nilai GAP dapat dilihat pada Persamaan (1) (Adhar, 2014).

GAP $=$ Nilai Seseorang - Nilai Standar

\section{Pembobotan}

Setelah mendapatkan nilai GAP, nilai GAP tersebut diberi bobot nilai dengan aturan pada Tabel 1 . 
Tabel 1. Bobot Nilai (Sumber: Adhar, 2014)

\begin{tabular}{|c|c|c|}
\hline GAP & $\begin{array}{c}\text { Bobot } \\
\text { Nilai }\end{array}$ & Keterangan \\
\hline 0 & 5 & Kompetensi sesuai yang dibutuhkan \\
\hline 1 & 4,5 & $\begin{array}{c}\text { Kompetensi individu kelebihan 1 } \\
\text { tingkat/level }\end{array}$ \\
\hline-1 & 4 & $\begin{array}{c}\text { Kompetensi individu kekurangan 1 } \\
\text { tingkat/level }\end{array}$ \\
\hline 2 & 3,5 & $\begin{array}{c}\text { Kompetensi individu kelebihan 2 } \\
\text { tingkat/level }\end{array}$ \\
\hline-2 & 3 & $\begin{array}{c}\text { Kompetensi individu kekurangan 2 } \\
\text { tingkat/level }\end{array}$ \\
\hline 3 & 2,5 & $\begin{array}{c}\text { Kompetensi individu kelebihan 3 } \\
\text { tingkat/level }\end{array}$ \\
\hline-3 & 2 & $\begin{array}{c}\text { Kompetensi individu kekurangan 3 } \\
\text { tingkat/level }\end{array}$ \\
\hline 4 & 1,5 & $\begin{array}{c}\text { Kompetensi individu kelebihan 4 } \\
\text { tingkat/level }\end{array}$ \\
\hline-4 & 1 & $\begin{array}{c}\text { Kompetensi individu kekurangan 4 } \\
\text { tingkat/level }\end{array}$ \\
\hline
\end{tabular}

3. Pengelompokan Core Factor dan Secondary Factor

Setelah menentukan bobot nilai GAP, tiap kriteria dikelompokkan menjadi core factor $(C F)$ dan secondary factor $(S F)$.

\section{Core Factor}

Core factor merupakan aspek yang paling dibutuhkan oleh suatu jabatan/posisi yang diperkirakan dapat menghasilkan kinerja optimal. Untuk menghitung core factor dapat menggunakan Persamaan (2).

$$
\mathrm{NCF}=\frac{\sum \mathrm{NC}}{\sum \mathrm{IC}}
$$

Dengan keterangan NCF adalah nilai rata-rata core factor, NC adalah jumlah nilai core factor, dan IC adalah jumlah banyaknya nilai core factor.

\section{Secondary Factor}

Secondary factor adalah nilai-nilai selain nilai yang ada pada core factor. Untuk menghitung secondary factor dapat menggunakan Persamaan (3).

$$
\mathrm{NSF}=\frac{\sum \mathrm{NS}}{\sum \mathrm{IS}}
$$

Dengan keterangan NSF adalah nilai rata-rata secondary factor, NS adalah jumlah nilai secondary factor, dan IS adalah jumlah banyaknya nilai secondary factor.

\section{Perhitungan Nilai Total}

Untuk menghitung nilai total dari NCF dan NSF, digunakan Persamaan (4).

$$
\mathrm{N}=(\mathrm{X}) \% \mathrm{NCF}+(\mathrm{X}) \% \mathrm{NSF}
$$

Dengan keterangan $\mathrm{N}$ adalah nilai total, $\mathrm{NCF}$ adalah nilai rata-rata core factor, NSF adalah nilai rata-rata secondary factor, dan (X)\% adalah nilai persentase.

\section{Perankingan}

Setelah melakukan proses profile matching, langkah terakhir adalah melakukan perangkingan untuk menemukan kandidat yang diinginkan (Kusrini, 2007).

\section{B. Nä̈ve Bayes}

Naïve Bayes merupakan salah satu algoritma klasifikasi (Kusrini, \& Lutfi, 2009). Lengkapnya adalah Nä̈ve Bayes merupakan teknik prediksi menggunakan probabilitas yang didasarkan pada penerapan teorema atau aturan Bayes dengan asumsi independensi yang naïf (Prasetyo, 2012). Independensi yang naif adalah bahwa sebuah fitur data tidak saling berkaitan dengan fitur dalam data lainnya yang sama.

Teorema Bayes yang merupakan memprediksi peluang dimasa depan menggunakan data yang sebelumnya dikombinasikan dengan Naive. Proses klasifikasi Nä̈ve Bayes memerlukan sejumlah data untuk menentukan kelas mana yang sama bagi sampel yang dianalisis.

Untuk memprediksi label kelas apakah "yes" atau "no" digunakan Persamaan (5).

$$
\mathrm{P}(\mathrm{Ci})
$$

Lalu menghitung banyaknya kondisi kasus yang sama menggunakan Persamaan (6).

$$
\mathrm{P}(\mathrm{X} \mid \mathrm{Ci})
$$

Terakhir, untuk menentukan kelas label untuk sampel adalah dengan Persamaan (7).

$$
\mathrm{P}(\mathrm{X} \mid \mathrm{Ci}) * \mathrm{P}(\mathrm{Ci})
$$

\section{Sepak Bola}

Sepak bola adalah olahraga yang dilakukan secara tim dengan masing-masing tim beranggotakan sebelas orang. Sepak bola bertujuan untuk mencetak gol sebanyak-banyaknya dengan memasukkan bola ke gawan lawan. Permainan sepak bola hampir menggunakan setiap bagian tubuh sehingga dibutuhkan teknik dalam berbagai aspek permainan. 


\section{Atribut Kemampuan}

Atribut kemampuan adalah nilai kemampuan dari kecakapan seorang individu untuk menguasai suatu tugas tertentu (Stephen P. Robbins \& Timonthy A. Judge, 2009). Atribut kemampuan yang digunakan adalah kemampuan atribut umum yang dimiliki oleh seorang pemain sepakbola.

\begin{tabular}{|c|c|c|}
\hline Crossing & Aggression & Acceleration \\
\hline Dribbling & Anticipation & Agility \\
\hline Finishing & Bravery & Balance \\
\hline First Touch & Composure & Jumping Reach \\
\hline Heading & Concentration & Pace \\
\hline Long Shots & Decisions & Stamina \\
\hline Marking & Determination & \\
\hline Passing & Flair & \\
\hline Tackling & Off the Ball & \\
\hline Technique & Positioning & \\
\hline Work Rate & Teamwork & \\
\hline Strength & Vision & \\
\hline
\end{tabular}

Nilai atribut kemampuan ini sangat berpengaruh terhadap performa pemain. Setiap pemain memiliki nilai atribut yang berbeda-beda sesuai kemampuan mereka masing-masing.

\section{E. Posisi dan Role}

Tim sepak bola menggunakan sebelas pemain sebagai starting eleven dengan tugasnya masingmasing. Secara umum posisi pemain terbagi menjadi empat, yaitu:
1. Penjaga Gawang/Goalkeeper

2. Pemain Bertahan/Back

3. Pemain Tengah/Midfielder

5. Pemain Depan/Striker

Namun, dari empat posisi umum pemain tersebut terdapat beberapa posisi khusus yang diantara-Nya adalah Advanced Forward, Attacking Midfielder, Inside Forward, Winger, Central Midfielder, Central Defense, Full-back, dan Wing-back.

Jika dilihat secara detail, setiap posisi pemain memiliki beberapa role yang berbeda-beda. Posisi role memiliki tugas yang berbeda-beda pula, sehingga setiap posisi role membutuhkan nilai atribut kemampuan yang penting untuk dimiliki oleh pemain agar dapat bermain secara optimal pada posisi role tersebut, nilai atribut kemampuan untuk kecocokan pemain dibagi menjadi dua yaitu key atribut dan atribut sisa.

Key atribut adalah atribut kemampuan yang penting dimiliki oleh pemain untuk mengisi posisi role tertentu sedangkan atribut sisa adalah atribut kemampuan yang tidak terlalu dibutuhkan pada posisi role tertentu.

Penentuan key atribut dan atribut sisa untuk setiap posisi role mengacu pada hasil interviu dengan pelatih SSB Bandung Private Centre yaitu Coach Noer Fahmi dengan standar tiap posisi yang berbeda-beda seperti pada Tabel 3 .

Tabel 3. Kriteria Standar Posisi

\begin{tabular}{|c|c|c|c|c|c|c|c|c|c|c|c|c|c|c|c|c|c|c|c|c|c|c|c|c|c|c|c|c|c|c|}
\hline Posisi & $\begin{array}{l}\text {. } \\
\text { 을 } \\
\text { 인 }\end{array}$ & 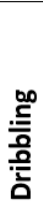 & 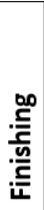 & 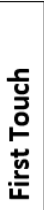 & 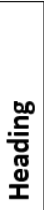 & 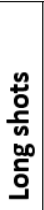 & 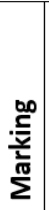 & 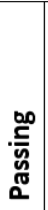 & 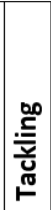 & 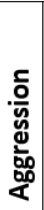 & 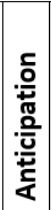 & $\frac{7}{0}$ & 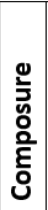 & 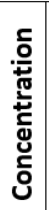 & 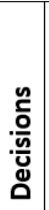 & 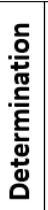 & $\frac{. \frac{1}{\pi}}{\frac{\pi}{4}}$ & 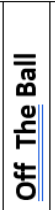 & 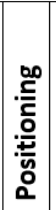 & 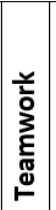 & $\frac{c}{\frac{0}{n}}$ & 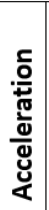 & 壱 & 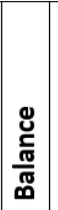 & 哭 & $\underset{\mathbb{0}}{ \pm}$ & 胥 & 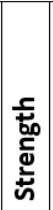 & 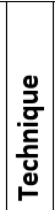 & 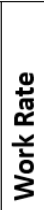 \\
\hline $\begin{array}{l}\text { Advanced } \\
\text { Forward }\end{array}$ & - & V & V & V & - & - & - & V & - & - & V & - & V & - & V & - & - & V & - & - & - & $\mathrm{V}$ & - & - & - & - & $\mathrm{V}$ & - & - & V \\
\hline $\begin{array}{l}\text { Attacking } \\
\text { Midfielder }\end{array}$ & - & V & - & V & - & V & - & V & - & - & - & - & V & - & - & - & - & V & - & - & $\mathrm{V}$ & - & $\mathrm{V}$ & - & - & - & - & - & $\mathrm{V}$ & - \\
\hline $\begin{array}{l}\text { Inside } \\
\text { Forward }\end{array}$ & - & V & - & - & - & V & - & V & - & - & - & - & - & - & - & - & - & $\mathrm{V}$ & - & - & V & $\mathrm{V}$ & $\mathrm{V}$ & - & - & - & - & - & V & - \\
\hline Winger & V & $\mathrm{V}$ & - & - & - & - & - & - & - & - & - & - & - & - & - & - & V & V & - & - & - & V & V & - & - & V & - & - & - & V \\
\hline $\begin{array}{l}\text { Central } \\
\text { Midfielder }\end{array}$ & - & - & - & V & - & V & - & V & - & - & - & - & V & - & - & - & - & - & - & V & $\mathrm{V}$ & - & - & - & - & - & V & - & V & V \\
\hline $\begin{array}{l}\text { Defensive } \\
\text { Midfielder }\end{array}$ & - & - & - & - & - & - & V & V & $\mathrm{V}$ & V & $\mathrm{V}$ & - & - & - & - & - & - & - & - & - & - & - & - & - & - & - & V & V & - & V \\
\hline $\begin{array}{l}\text { Central } \\
\text { Defense }\end{array}$ & - & - & - & - & V & - & $\mathrm{V}$ & - & V & - & $\mathrm{V}$ & V & V & $\mathrm{V}$ & V & - & - & - & V & - & - & - & - & - & $\mathrm{V}$ & - & - & V & - & - \\
\hline Full-back & V & - & - & - & - & - & V & - & V & - & $\mathrm{V}$ & - & - & - & $\mathrm{V}$ & - & - & - & - & - & - & - & - & - & - & $\mathrm{V}$ & V & - & - & - \\
\hline $\begin{array}{l}\text { Wing- } \\
\text { back }\end{array}$ & V & V & - & - & - & - & $\mathrm{V}$ & - & $\mathrm{V}$ & - & $\mathrm{V}$ & - & - & V & $\mathrm{V}$ & - & - & $\mathrm{V}$ & - & - & - & V & $\mathrm{V}$ & - & - & V & V & - & V & V \\
\hline
\end{tabular}

(Sumber: Hasil wawancara dengan Coach Noer Fahmi pelatih SSB Bandung Private Centre, 2020)

\section{F. Football Manager}

Football Manager adalah permainan game simulasi buatan Sports Interactive dimana user atau pemain menjadi manajer sebuah tim sepak bola. Pada game ini, manajer dapat mengatur formasi tim, strategi tim, rutinitas latihan, keuangan tim, hingga 
pembelian pemain. Pada awalnya game ini bernama Championship Manager saat pertama kali rilis pada tahun 1992. Namun, Sports Interactive mengubah nama game ini menjadi Football Manager dengan penerbit baru yaitu SEGA, hal ini dikarenakan putusnya kemitraan dengan Eidos Interactive sehingga kehilangan hak penamaan.

\section{METODE PENELITIAN}

\section{A. Blok Diagram}

Blok diagram adalah suatu perencanaan alat yang mana di dalamnya terdapat inti dari pembuatan modul tersebut.

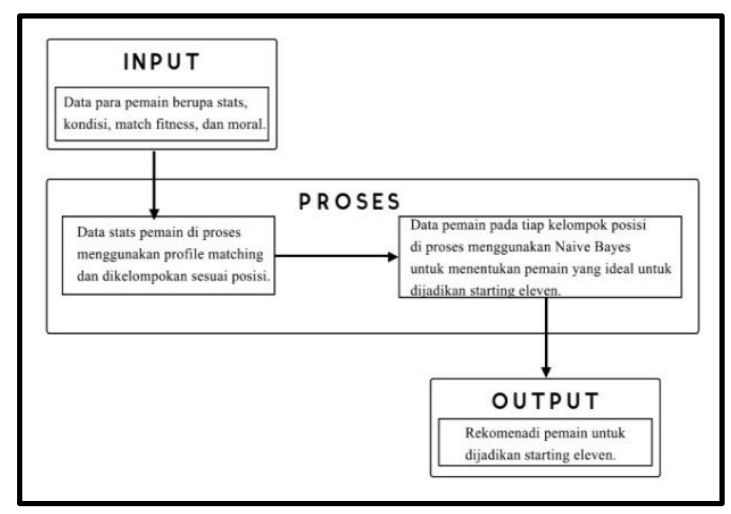

Gambar 1. Blok Diagram

Data-data pemain seperti nilai atribut stats, kebugaran pemain, match fitness, dan moral pemain dimasukan sebagai data pemain. Data tersebut diproses oleh sistem menggunakan profile matching untuk menentukan posisi role yang ideal untuk pemain tersebut. Hasil data pemain setelah dilakukan profile matching dikelompokkan sesuai posisi role ideal mereka. Data kelompok tersebut dilakukan proses pemilihan pemain untuk starting eleven dari setiap kelompok posisi menggunakan metode Nä̈ve Bayes. Hasil data setelah dilakukan metode Naïve Bayes adalah data pemain yang terpilih sebagai starting eleven pada setiap kelompok posisi role.

\section{B. Tahap Konversi Nilai Atribut}

Sample data yang digunakan adalah data pemain Ben Woodburn dengan nilai atribut kemampuan pada Tabel 4.

Tabel 4. Nilai Atribut Ben Woodburn
\begin{tabular}{|l|c|l|c|l|c|}
\hline Crossing & 13 & Aggression & 11 & Teamwork & 13 \\
\hline Dribbling & 14 & Anticipation & 13 & Vision & 14 \\
\hline Finishing & 14 & Bravery & 11 & Work Rate & 13 \\
\hline First Touch & 14 & Composure & 14 & Acceleration & 14 \\
\hline Heading & 8 & Concentration & 13 & Agility & 13 \\
\hline Long Shots & 11 & Decisions & 13 & Balance & 12 \\
\hline Marking & 8 & Determination & 15 & Jumping & 7 \\
\hline Passing & 14 & Flair & 14 & Pace & 13 \\
\hline Tackling & 12 & Off the Ball & 14 & Stamina & 10 \\
\hline Technique & 15 & Positioning & 8 & Strength & 10 \\
\hline
\end{tabular}

Nilai atribut kemampuan pemain dilakukan konversi dengan aturan pada Tabel 5.
Tabel 5. Aturan Konversi

\begin{tabular}{|c|c|}
\hline Range nilai atribut stats & Nilai Bobot \\
\hline $17-20$ & 5 \\
\hline $13-16$ & 4 \\
\hline $9-12$ & 3 \\
\hline $5-8$ & 2 \\
\hline $1-4$ & 1 \\
\hline
\end{tabular}

Sehingga menghasilkan data seperti ini:

Tabel 6. Nilai Hasil Konversi

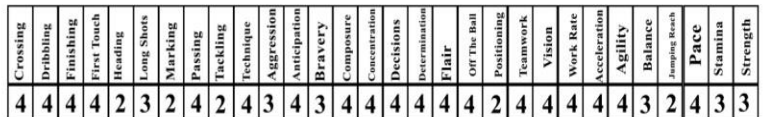

\section{Tahap Penentuan Nilai GAP}

Penentuan nilai GAP adalah perbedaan nilai yang dimiliki seseorang dengan nilai yang diinginkan sesuai dengan standar (Setiabudi, 2012).

Berikut adalah persamaan untuk menentukan nilai GAP:

GAP $=$ Kriteria Seseorang - Kriteria Diinginkan $(8)$

Kriteria yang diinginkan pada penelitian ini merupakan data primer hasil wawancara dengan Coach Noer Fahmi. Dengan kriteria pada tiap posisi seperti pada Tabel 3.

Hasil perhitungan nilai GAP pada posisi winger untuk Ben Woodburn setelah dikurangi dengan nilai standar winger dapat dilihat pada Tabel 7 .

Tabel 7. Hasil GAP Posisi Winger

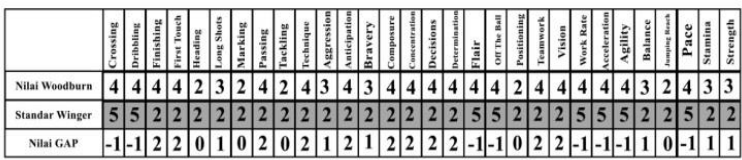

Hasil perhitungan nilai GAP pada posisi Advanced Forward untuk Ben Woodburn setelah dikurangi dengan nilai standar Advanced Forward dapat dilihat pada Tabel 8 .

Tabel 8. Hasil GAP Posisi Advanced Forward

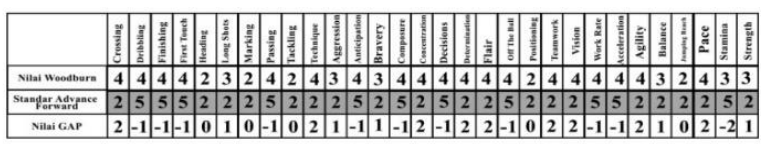

\section{Tahap Pembobotan}

Setelah mendapatkan nilai GAP, hasil dari nilai GAP tersebut diberikan bobot nilai sesuai dengan aturan pada Tabel 1 bobot nilai. Berdasarkan Tabel 7 yang merupakan hasil nilai GAP pada posisi winger dan Tabel 8 yang merupakan hasil nilai GAP pada posisi Advanced Forward dilakukan pembobotan berdasarkan ketentuan pada Tabel 1 . 
Sehingga menghasilkan tabel hasil pembobotan seperti pada Tabel 9.

Tabel 9. Hasil Pembobotan

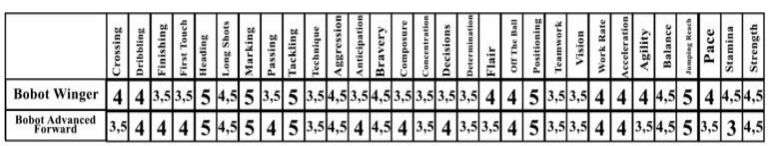

\section{E. Perhitungan Nilai Core Factor, Nilai Seconday Factor, dan Nilai Total}

Nilai Core Factor merupakan nilai key attribute dan secondary attribute, sedangkan nilai Secondary Factor adalah nilai attribute lainnya.

Untuk mencari Nilai Core Factor, digunakan Persamaan (2). Sehingga hasil perhitungan nilai Core Factor untuk posisi adalah sebagai berikut:

$$
\mathrm{NFC}=\frac{4+4+4+4+4+4+4+3,5}{8}=3,9375
$$

Hasil perhitungan nilai Core Factor untuk posisi Advanced Forward adalah sebagai berikut:

$$
\mathrm{NFC}=\frac{4+4+4+4+4+4+4+4+3+4+4}{11}=3,909
$$

Sedangkan untuk mencari nilai Secondary Factor digunakan Persamaan (3). Sehingga hasil perhitungan nilai Secondary Factor untuk posisi winger adalah sebagai berikut:

$$
\mathrm{NSF}=\frac{\begin{array}{c}
3,5+3,5+5+4,5+5+3,5+5+3,5+4,5+3,5+4,5+ \\
3,5+3,5+3,5+3,5+5+3,5+3,5+4,5+5+4,5+4,5
\end{array}}{22}
$$

Hasil perhitungan nilai Secondary Factor untuk posisi Advanced Forward adalah sebagai berikut:

$$
\mathrm{NSF}=\frac{\begin{array}{c}
3,5+5+4,5+5+5+3,5+4,5+4,5+3,5+3,5+3,5+5 \\
+3,5+3,5+3,5+4,5+5+3,5+4,5 \\
19
\end{array} 4,157894}{}
$$

Dari hasil nilai Core factor dan nilai Secondary Factor yang telah didapat, maka dapat dihitung nilai totalnya menggunakan Persamaan (4). Sehingga hasil nilai total untuk posisi winger adalah sebagai berikut:

$$
\mathrm{N}=(60 \% \times 3,9375)+(40 \% \times 4,4772)=4,15338
$$

Sedangkan hasil nilai total untuk posisi Advanced Forward adalah sebagai berikut:

$$
\mathrm{N}=(60 \% \times 3,909)+(40 \% \times 4,157894)=4.008558
$$

Dari hasil rangking nilai total untuk posisi winger dan advanced forward dapat disimpulkan bahwa posisi ideal bagi Ben Woodburn adalah Winger dengan nilai 4,15338 .

\section{F. Penentuan Starting Eleven}

Setelah mendapatkan posisi ideal untuk Ben Woodburn yaitu Winger, maka diasumsikan terdapat beberapa pemain lainnya yang berada di kelompok posisi Winger. Untuk menentukan pemain mana yang baik untuk dipilih sebagai starting eleven, dilakukan proses Nä̈ve Bayes.

Tabel ini berisi data pemain lainnya pada kelompok Winger, 10 data yang diambil sudah mencakup dari semua kriteria yang ada.

Tabel 10. Data Latih Pemain

\begin{tabular}{|l|c|c|c|c|c|}
\hline \multicolumn{1}{|c|}{ Nama } & Ability & $\begin{array}{c}\text { Kondisi } \\
\text { Kebugaran }\end{array}$ & $\begin{array}{c}\text { Match } \\
\text { Fitness }\end{array}$ & Moral & $\begin{array}{c}\text { Starting } \\
\text { Eleven }\end{array}$ \\
\hline $\begin{array}{l}\text { Harry } \\
\text { Wilson }\end{array}$ & 4 & Fit & $\begin{array}{c}\text { Sangat } \\
\text { Tajam }\end{array}$ & Tinggi & Yes \\
\hline $\begin{array}{l}\text { Lazar } \\
\text { Markovic }\end{array}$ & 3 & Fit & $\begin{array}{c}\text { Sangat } \\
\text { Tajam }\end{array}$ & Normal & Yes \\
\hline $\begin{array}{l}\text { Divock } \\
\text { Origi }\end{array}$ & 1 & Fit & $\begin{array}{c}\text { Sangat } \\
\text { Tajam }\end{array}$ & Normal & No \\
\hline $\begin{array}{l}\text { Marcus } \\
\text { Taverneir }\end{array}$ & 3 & Fit & Tajam & Rendah & No \\
\hline $\begin{array}{l}\text { Rhian } \\
\text { Brewster }\end{array}$ & 3 & Kurang Fit & Tajam & Normal & No \\
\hline $\begin{array}{l}\text { Harvey } \\
\text { Elliot }\end{array}$ & 3 & Fit & $\begin{array}{l}\text { Sangat } \\
\text { Tajam }\end{array}$ & Rendah & No \\
\hline $\begin{array}{l}\text { Takumi } \\
\text { Minamino }\end{array}$ & 3 & Tidak Fit & $\begin{array}{l}\text { Sangat } \\
\text { Tajam }\end{array}$ & Tinggi & No \\
\hline $\begin{array}{l}\text { Mohamed } \\
\text { Salah }\end{array}$ & 4 & Tidak Fit & $\begin{array}{l}\text { Sangat } \\
\text { Tajam }\end{array}$ & Tinggi & No \\
\hline $\begin{array}{l}\text { Sadio } \\
\text { Mane }\end{array}$ & 4 & Fit & Tajam & Normal & Yes \\
\hline $\begin{array}{l}\text { Xherdan } \\
\text { Shaqiri }\end{array}$ & 4 & Fit & $\begin{array}{c}\text { Tidak } \\
\text { Tajam }\end{array}$ & Normal & Yes \\
\hline
\end{tabular}

Data Ben Woodburn dimasukkan ke dalam sistem dan di olah dengan Nä̈ve Bayes dengan data sebagai berikut:

Tabel 11. Kondisi Ben Woodburn

\begin{tabular}{|l|c|c|c|c|}
\hline Nama & Rating & $\begin{array}{l}\text { Kondisi } \\
\text { Kebugaran }\end{array}$ & $\begin{array}{l}\text { Match } \\
\text { Fitness }\end{array}$ & Moral \\
\hline $\begin{array}{l}\text { Ben } \\
\text { Woodburn }\end{array}$ & 3 & Fit & $\begin{array}{l}\text { Sangat } \\
\text { Tajam }\end{array}$ & Normal \\
\hline
\end{tabular}

Nilai rating didapatkan dari konversi nilai rata-rata atribut yang sebesar 12,66 menjadi 3 menggunakan aturan pada Tabel 12 .

Tabel 12. Aturan Konversi Nilai Rata-rata

\begin{tabular}{|c|c|}
\hline Range rata-rata nilai & Nilai Bobot \\
\hline $16-20$ & 4 \\
\hline $11-15$ & 3 \\
\hline $6-10$ & 2 \\
\hline $1-5$ & 1 \\
\hline
\end{tabular}

1. Hitung $\mathrm{P}(\mathrm{Ci})$

$\mathrm{P}($ Starting Eleven $=$ "Yes" $)=4 / 10=0,4$

$\mathrm{P}($ Starting Eleven $=$ "No" $)=6 / 10=0,6$ 
2. Hitung $\mathrm{P}(\mathrm{X} \mid \mathrm{Ci})$

Menghitung banyaknya kondisi kasus yang sama:

$\mathrm{P}($ Rating $=$ "3" $\mid$ Starting Eleven $=$ "Yes" $)=1 / 5=$ 0,2

$\mathrm{P}($ Rating $=$ "3" $\mid$ Starting Eleven $=$ "No") $=4 / 5=$ 0,8

$\mathrm{P}($ Kondisi Kebugaran $=$ "Fit" $\mid$ Starting Eleven = "Yes") $=5 / 7=0,714$

$\mathrm{P}($ Kondisi Kebugaran $=$ "Fit" $\mid$ Starting Eleven $=$ "No") $=2 / 7=0,285$

$\mathrm{P}($ Match Fitness= "Sangat Tajam" | Starting Eleven $=$ "Yes") $=3 / 6=0,5$

$\mathrm{P}($ Match Fitness= "Sangat Tajam" | Starting Eleven $=$ "No") $=3 / 6=0,5$

$\mathrm{P}($ Moral= "Normal" | Starting Eleven = "Yes") = $3 / 5=0,6$

$\mathrm{P}($ Moral = "Normal" $\mid$ Starting Eleven $=$ "No") $=2 / 5$ $=0,4$

Dari hasil perhitungan jumlah kasus, kalikan semua hasil variabel yang didapat:

$\mathrm{P}(\mathrm{X} \mid$ Starting Eleven $=$ "Yes") $=0,2 \times 0,714 \times 0,5$ $\times 0,6=0,04284$

$\mathrm{P}(\mathrm{X} \mid$ Starting Eleven $=$ "No" $)=0,8 \times 0,285 \times 0,5$ $\times 0,4=0,0456$

3. Hitung $\mathrm{P}(\mathrm{X} \mid \mathrm{Ci}) * \mathrm{P}(\mathrm{Ci})$

$\mathrm{P}($ Starting Eleven="Yes") $=0,04284 \times 0,4=0,017136$

$\mathrm{P}($ Starting Eleven $=$ "No" $)=0,0456 \times 0,6=0,02736$

Dari hasil perhitungan diatas, nilai "Yes" pada starting eleven Ben Woodburn sebesar 0,017136. Nilai tersebut akan dilakukan perangkingan dengan nilai pemain Winger lainnya.

\section{HASIL DAN PEMBAHASAN}

Pada penelitian ini dilakukan pengujian akurasi perbandingan antara rekomendasi posisi ideal pemain dengan posisi aslinya menggunakan 20 data pemain Manchester United.

\section{A. Akurasi Rekomendasi Posisi Pemain}

Dari 20 data pemain yang digunakan, berdasarkan pengujian pada penelitian ini, diperoleh rekomendasi posisi ideal pemain. Perbedaan posisi asli pemain dengan posisi rekomendasi dari sistem dapat dilihat pada Tabel 13.
Tabel 13. Perbedaan Posisi Pemain

\begin{tabular}{|c|c|c|}
\hline Nama & Posisi Asli & $\begin{array}{c}\text { Posisi } \\
\text { Rekomendasi }\end{array}$ \\
\hline Ander Herrera & $\begin{array}{c}\text { Central } \\
\text { Midfielder, } \\
\text { Defensive } \\
\text { Midfielder }\end{array}$ & $\begin{array}{l}\text { Defensive } \\
\text { Midfielder }\end{array}$ \\
\hline Chris Smalling & Central Defense & Central Defense \\
\hline Eric Bailly & Central Defense & Central Defense \\
\hline Ashley Young & $\begin{array}{c}\text { Wing-back, } \\
\text { Winger }\end{array}$ & Wing-back \\
\hline Phil Jones & Central Defense & $\begin{array}{l}\text { Defensive } \\
\text { Midfielder }\end{array}$ \\
\hline Nemanja Matic & $\begin{array}{c}\text { Defensive } \\
\text { Midfielder, } \\
\text { Central } \\
\text { Midfielder }\end{array}$ & Central Defense \\
\hline Paul Poga & $\begin{array}{c}\text { Central } \\
\text { Midfielder, } \\
\text { Attacking } \\
\text { Midfielder }\end{array}$ & Central Midfielder \\
\hline Fred & $\begin{array}{l}\text { Defensive } \\
\text { Midfielder, } \\
\text { Central } \\
\text { Midfielder }\end{array}$ & $\begin{array}{l}\text { Attacking } \\
\text { Midfielder }\end{array}$ \\
\hline Fellaini & $\begin{array}{c}\text { Central } \\
\text { Midfielder, } \\
\text { Attacking } \\
\text { Midfielder }\end{array}$ & Central Defense \\
\hline Marcus Rashford & $\begin{array}{l}\text { Inside Forward, } \\
\text { Winger, } \\
\text { Advanced } \\
\text { Forward } \\
\end{array}$ & Advanced Forward \\
\hline Martial & $\begin{array}{l}\text { Inside Forward, } \\
\text { Winger, } \\
\text { Advanced } \\
\text { Forward } \\
\end{array}$ & Winger \\
\hline Diogo Dalot & $\begin{array}{c}\text { Full-back, Wing- } \\
\text { back }\end{array}$ & Wing-back \\
\hline Pereira & $\begin{array}{c}\text { Central } \\
\text { Midfielder, } \\
\text { Attacking } \\
\text { Midfielder }\end{array}$ & $\begin{array}{l}\text { Attacking } \\
\text { Midfielder }\end{array}$ \\
\hline Scott McTominay & $\begin{array}{c}\text { Central } \\
\text { Midfielder }\end{array}$ & $\begin{array}{l}\text { Defensive } \\
\text { Midfielder }\end{array}$ \\
\hline Jesse Lingard & $\begin{array}{c}\text { Inside Forward, } \\
\text { Winger, Attacking } \\
\text { Midfielder }\end{array}$ & Advanced Forward \\
\hline Alexis Sanchez & $\begin{array}{l}\text { Inside Forward, } \\
\text { Winger, } \\
\text { Advanced } \\
\text { Forward }\end{array}$ & Inside Forward \\
\hline Lindelof & Central Defense & $\begin{array}{l}\text { Defensive } \\
\text { Midfielder }\end{array}$ \\
\hline Luke Shaw & $\begin{array}{l}\text { Wing-back, Full- } \\
\text { back }\end{array}$ & Wing-back \\
\hline Juan Mata & $\begin{array}{c}\text { Attacking } \\
\text { Midfielder } \\
\end{array}$ & $\begin{array}{l}\text { Attacking } \\
\text { Midfielder }\end{array}$ \\
\hline Lukaku & $\begin{array}{l}\text { Advanced } \\
\text { Forward }\end{array}$ & Advanced Forward \\
\hline
\end{tabular}

(Sumber: Hasil penelitian, 2020)

Dari 20 pemain, 13 pemain direkomendasikan posisi yang sama dengan posisi aslinya. Perhitungan tingkat akurasi rekomendasi posisi ideal pemain yaitu $\frac{13}{20} \times 100 \%=65 \%$. 


\section{B. Kenaikan Rating Rata-Rata Tim}

Pengujian dengan melakukan pertandingan menggunakan starting eleven default dan starting eleven rekomendasi pemain masing-masing sebanyak 10 kali percobaan melawan tim dengan komposisi pemain yang sama.

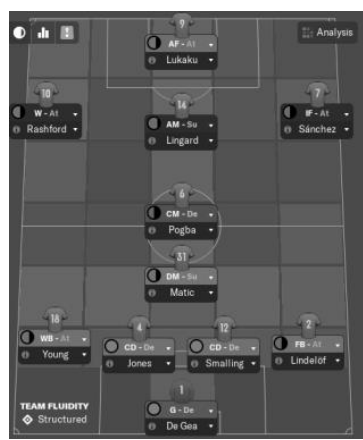

Gambar 2. Formasi Default

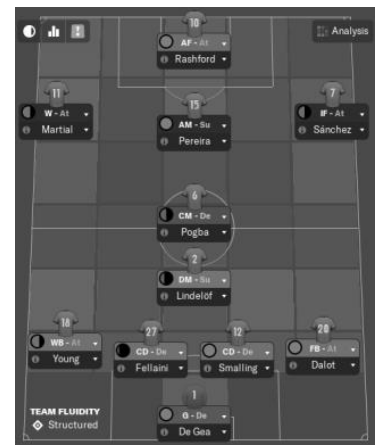

Gambar 3. Formasi Pemain Rekomendasi

Pada Gambar 2 dan Gambar 3, ada beberapa perbedaan komposisi pemain pada formasi default dengan formasi pemain rekomendasi. Perbedaan pemain dari kedua formasi dapat dilihat pada Tabel 14.

Tabel 14. Perbedaan Komposisi Pemain

\begin{tabular}{|c|c|c|}
\hline \multirow{2}{*}{ Posisi } & \multicolumn{2}{|c|}{ Nama Pemain } \\
\hline & Default & Rekomendasi \\
\hline Advanced Forward (AF) & Lukaku & $\begin{array}{l}\text { Marcus } \\
\text { Rashford }\end{array}$ \\
\hline Winger (W) & $\begin{array}{l}\text { Marcus } \\
\text { Rashford }\end{array}$ & Martial \\
\hline Inside Forward (IF) & Alexis Sanchez & Alexis Sanchez \\
\hline $\begin{array}{l}\text { Attacking Midfielder } \\
\text { (AM) }\end{array}$ & Jesse Lingard & Pereira \\
\hline $\begin{array}{l}\text { Defensive Midfielder } \\
\text { (DM) }\end{array}$ & Matic & Lindelof \\
\hline Central Midfielder (CM) & Paul Pogba & Paul Pogba \\
\hline Central Defense (CD1) & Chris Smalling & Chris Smalling \\
\hline Central Defense (CD2) & Phil Jones & Fellaini \\
\hline Wing-back (WB) & Ashley Young & Ashley Young \\
\hline Full-back (FB) & Lindelof & Diego Dalot \\
\hline Goalkeeper (GK) & David De Gea & David De Gea \\
\hline
\end{tabular}

(Sumber: Hasil penelitian, 2020)

Dari 10 kali percobaan menggunakan starting eleven default, didapatkan rating pemain seperti pada Tabel 15.

Tabel 15. Rating Starting Eleven Default

\begin{tabular}{|c|c|c|c|c|c|c|c|c|c|c|}
\hline Percobaan & CD1 & CD2 & WB & DM & CM & IF & AM & W & AF \\
\hline 1 & 6 & 6.3 & 6.2 & 6.5 & 6.5 & 6.4 & 6.6 & 7.7 & 6.7 \\
\hline 2 & 6.6 & 7.4 & 6.4 & 6.4 & 7.1 & 6.3 & 6.3 & 6.4 & 6.6 \\
\hline 3 & 6.8 & 6.7 & 6.1 & 6.5 & 7.6 & 6.6 & 6.2 & 6.4 & 6.7 \\
\hline 4 & 6.5 & 6.5 & 6.7 & 6.1 & 6.4 & 7 & 6.6 & 7 & 6.6 \\
\hline 5 & 6.2 & 6.3 & 6.6 & 6.7 & 6.8 & 6.3 & 6.1 & 6.1 & 7 \\
\hline 6 & 6.7 & 6.7 & 6.9 & 8.3 & 8.3 & 6.4 & 6.5 & 6.4 & 6.6 \\
\hline 7 & 6.3 & 6.7 & 6.7 & 6.7 & 7.4 & 6.4 & 7 & 6.2 & 6.4 \\
\hline 8 & 6.5 & 6.4 & 6.4 & 6.5 & 7.3 & 6.7 & 8.8 & 6.7 & 6.3 \\
\hline 9 & 6.8 & 6.6 & 6.8 & 6.4 & 6.8 & 6.2 & 6.5 & 6.4 & 6 \\
\hline 10 & 6.2 & 6.1 & 6.8 & 6.2 & 6.6 & 7.7 & 6.2 & 7.1 & 6.9 \\
\hline Rata-rata & 6.46 & 6.57 & 6.56 & 6.63 & 7.08 & 6.6 & 6.68 & 6.64 & 6.58 \\
\hline $\begin{array}{c}\text { Rata-rata } \\
\text { tim }\end{array}$ & $\mathbf{6 . 6 4 4 4 4 4 4 4}$ & & & & & &
\end{tabular}

(Sumber: Hasil penelitian, 2020) 
Sedangkan dari 10 kali percobaan menggunakan starting eleven pemain rekomendasi, didapatkan rating pemain seperti pada Tabel 16 .

Tabel 16. Rating Starting Eleven Pemain Rekomendasi

\begin{tabular}{|c|c|c|c|c|c|c|c|c|c|}
\hline Percobaan & CD1 & CD2 & WB & DM & CM & IF & AM & W & AF \\
\hline 1 & 6.4 & 6.9 & 6.5 & 6.6 & 6.4 & 7.6 & 7 & 8.1 & 9.5 \\
\hline 2 & 6.7 & 6.5 & 5.6 & 6.3 & 6.9 & 5.6 & 6.3 & 6.3 & 6.2 \\
\hline 3 & 6.3 & 6.5 & 5.9 & 5.7 & 8.5 & 6.4 & 6.7 & 6.2 & 7 \\
\hline 4 & 6.7 & 6.5 & 6.9 & 7.5 & 6.7 & 8.8 & 6.9 & 8.8 & 7.3 \\
\hline 5 & 6.3 & 6.2 & 6.8 & 6.4 & 6.5 & 7.1 & 6.4 & 6.4 & 6 \\
\hline 6 & 6.2 & 6.4 & 6 & 6.9 & 6.6 & 6.6 & 6.5 & 6.8 & 6.9 \\
\hline 7 & 6.7 & 7.1 & 6.4 & 6.8 & 6.6 & 6.5 & 6.5 & 7.2 & 7 \\
\hline 8 & 6.7 & 6.7 & 6.1 & 6.6 & 6.6 & 6.7 & 8.3 & 7.3 & 7 \\
\hline 9 & 6.1 & 6.4 & 6.3 & 6.7 & 6.6 & 6.7 & 6.6 & 8.8 & 6.7 \\
\hline 10 & 6.2 & 6 & 6.1 & 6.7 & 6.7 & 6 & 6.2 & 6.5 & 6.1 \\
\hline \begin{tabular}{c} 
Rata-rata \\
\hline
\end{tabular} & 6.43 & 6.52 & 6.26 & 6.62 & 6.81 & 6.8 & 6.74 & 7.24 & 6.97 \\
\hline $\begin{array}{l}\text { Rata-rata } \\
\text { tim }\end{array}$ & 6.71 & & & & & & &
\end{tabular}

(Sumber: Hasil penelitian, 2020)

Karena pada pengujian ini kiper tidak ada pada pilihan posisi rekomendasi dan tidak ada pemain rating kiper dan full-back tidak dimasukkan dalam perhitungan rata-rata tim.

Tabel 17 Selisih Rating Tiap Posisi

\begin{tabular}{|c|c|c|c|c|c|c|c|c|c|}
\hline & CD1 & CD2 & WB & DM & CM & IF & AM & W & AF \\
\hline Default & 6.46 & 6.57 & 6.56 & 6.63 & 7.08 & 6.6 & 6.68 & 6.64 & 6.58 \\
\hline Rekomendasi & 6.43 & 6.52 & 6.26 & 6.62 & 6.81 & 6.8 & 6.74 & 7.24 & 6.97 \\
\hline Selisih & -0.03 & -0.05 & -0.3 & -0.01 & -0.27 & 0.2 & 0.06 & 0.6 & 0.39 \\
\hline Persentase & $-0.47 \%$ & $-0.77 \%$ & $-4.79 \%$ & $-0.15 \%$ & $-3.96 \%$ & $2.94 \%$ & $0.89 \%$ & $8.29 \%$ & $5.60 \%$ \\
\hline
\end{tabular}

(Sumber: Hasil penelitian, 2020)

Dari Tabel 17, dapat diketahui bahwa beberapa posisi mengalami penurunan rata-rata rating setelah dilakukan rekomendasi pemain yaitu Central Defense 1 sebanyak 0,47\%, Central Defense 2 sebanyak 0,77\%, Wing-back sebanyak 4,79\%, Defensive Midfielder sebanyak 0,15\%, dan Central Midfielder sebanyak 3,96\%. Sedangkan posisi lainnya mengalami kenaikan rata-rata rating setelah dilakukan rekomendasi pemain yaitu Inside Forward sebanyak 2,94\%, Attacking Midfielder sebanyak $0,89 \%$, Winger sebanyak 8,29\%, dan Advanced Forward sebanyak 5,60\%.
Tabel 18. Selisih Rating Rata-rata Tim

\begin{tabular}{|l|c|}
\hline Nilai Rata-rata Tim Default & 6.644444 \\
\hline $\begin{array}{l}\text { Nilai Rata-rata Tim } \\
\text { Rekomendasi }\end{array}$ & 6.71 \\
\hline Selisih & 0.065556 \\
\hline Persentase & $0.98 \%$ \\
\hline
\end{tabular}

(Sumber: Hasil penelitian, 2020)

Jika dilihat pada Tabel 18, dapat diketahui bahwa rata-rata rating tim rekomendasi lebih besar dari rata-rata rating tim default dengan rata-rata kenaikannya sebesar $0,98 \%$. 


\section{KESIMPULAN DAN SARAN}

\section{A. Kesimpulan}

Berdasarkan pengujian yang telah dilakukan menggunakan 20 data pemain Manchester United, tingkat akurasi antara posisi asli pemain dengan penggunaan profile matching dalam menentukan posisi ideal pemain mencapai $65 \%$. Sedangkan untuk pemilihan pemain starting eleven memiliki hasil yang beragam untuk tiap-tiap posisi, beberapa posisi mengalami penurunan rata-rata rating setelah dilakukan rekomendasi pemain yaitu Central Defense 1 sebanyak 0,47\%, Central Defense 2 sebanyak 0,77\%, Wing-back sebanyak 4,79\%, Defensive Midfielder sebanyak 0.15\%, dan Central Midfielder sebanyak 3,96\%. Sedangkan posisi lainnya mengalami kenaikan rata-rata rating setelah dilakukan rekomendasi pemain yaitu Inside Forward sebanyak 2,94\%, Attacking Midfielder sebanyak $0,89 \%$, Winger sebanyak 8,29\%, dan Advanced Forward sebanyak 5,60\%. Namun, karena nilai yang dicari adalah kenaikan rating performa tim, maka dilakukan rata-rata rating tim setelah dilakukan pemilihan rekomendasi pemain dengan nilai mengalami kenaikan sebesar $0,98 \%$.

\section{B. Saran}

Berikut ini adalah beberapa saran yang dapat dilakukan pada penelitian selanjutnya:

1. Menambahkan posisi Goal Keeper pada pilihan rekomendasi pemain.

2. Pengujian dapat dilakukan pada pemain dan pertandingan asli.

\section{DAFTAR PUSTAKA}

Adhar, D. (2014). Sistem Pendukung Keputusan Pengangkatan Jabatan Karyawan pada PT.Ayn dengan Metode Profile Matching. Jatisi, Vol. 1 No. 1 September 2014, 16-29.

Sartika, D., Andreswari, D., \& Anggriani, K. (2016). Sistem Pendukung Keputusan Penentuan Posisi Ideal Pemain Dalam Cabang Olahraga Sepak Bola Dengan Menggunakan Pendekatan Dua Metode Naive Bayes dan Profile Matching. Jurnal Rekursif,. 4, 3, 311-324.

Yaqin, M. A., \& Humami, A. G. (2019). Optimasi Pemilihan Posisi Terbaik Pemain Muda Pada Game Football Manager 2018 Dengan Metode Naïve Bayes. Seminar Nasional Inovasi dan Aplikasi Teknologi di Industri 2019 (pp. 59-65). Malang: SENIATI 2019 Institut Teknologi Nasional Malang.

Alprianta, H., Honggowibowo, A. S., \& Indrianingsih, Y. (2012). Sistem Pendukung Keputusan Untuk Menentukanposisi Pemain Ideal Dalam Tim Sepak Bola Denganmetode Algoritma Genetika. Compiler, 1(2), 39-50.
Asrianda, D, R. K., \& Hidayat, R. (2019). Sistem Pendukung Keputusan Seleksi Pemain Bola Menggunakan Metode Analytical Hierarchy Process (AHP) . TECHSI: 11(2), Juli2019, 280-288

Dedi, I., Putra P, D., \& Aswi, R. (2015). Sistem Pendukung Keputusan Penentuan Posisi Pemaindalam Strategi Formasi Futsal. Semnas tekno media Online, 79-83.

Kusrini, \& Luthfi, E. T. (2009). Algoritma data mining. Yogyakarta: Andi Offset.

Kusrini, K. (2007). Aplikasi Sistem Pendukung Keputusan. Yogyakarta: Andi Offset.

Prasetyo, E. (2012). Data Mining Konsep dan Aplikasi Menggunakan Matlab. Yogyakarta: Andi.

Robbins, S. P., \& Judge, T. A. (2009). Organizational Behavior. 13 Three Edition. USA: Pearson International Edition, Prentice -Hall.

Setiabudi, E. (2012). Sistem penunjang keputusan untuk penerimaan karyawan baru pada PT. pupuk kalimantan timur. AMIKOM. 